\title{
The Protection of Human Rights of the Witness and Victim during Criminal Proceeding
}

\author{
Abdul Salam Siku \\ Faculty of Law, 45 University of Makassar - Indonesia \\ Muhadar \\ Faculty of Law, 45 University of Makassar - Indonesia \\ M.Said Karim \\ Faculty of Law, 45 University of Makassar - Indonesia
}

Accepted: November 01, 2012 Published: December 20, 2012

Doi:10.5296/jsr.v3i2.2917ＵRL: http://dx.doi.org/10.5296/jsr.v3i2.2917

\begin{abstract}
The research is aimed at understanding the application of the legal substance of Act No. 13 of 2006 about the Protection of Human Rights of The Witness and Victim during Criminal Proceeding. This protection covers the right over obtaining protection for the security, the right over giving statement without pressure and the right over obtaining legal advice. This research is conducted at Jakarta and South Sulawesi Province (in Makassar and Bone District). Two research approaches are used. Normative approach is applied by examining secondary data, while non-doctrinal approach is carried out by synchronizing the prevailed law and the empirical reality in the community. Research type is qualitative with the analytical descriptive pattern to explain and to illustrate the protection of human rights of the witness and victim during criminal proceeding. Result of research indicates that the protection of human rights of the witness and victim during criminal proceeding is not effectively provided, especially for the right over obtaining protection for the security, the right over giving statement without pressure and the right over obtaining legal advice.
\end{abstract}

Keywords: Protection, Human Rights, Witness, Victim

\section{Introduction}

\subsection{Background}

Article 28 D Verse (1) of National Constitution has determined that everyone has a right over confession, guarantee, protection and legal certainty in the just or equal bases before the law. It is further explained through Article $28 \mathrm{G}$ Verse (1) of National Constitution that everyone has a right over protection for the self, family, respect, dignity and wealth in their possession, 
and everyone has a right for feeling safe and protected against threat or violation of human rights, Packer, (Herbert,1968). The protection of the witness and victim during criminal proceeding in Indonesia is regulated under the Act of Protection of The Witness and Victim which is prevailed since August 11 of 2006, (Iswanto, 1998).

It is mentioned in this Act that based on the equality before the law, as one marker of legal country, the witness and victim shall be given guarantee of protection of their human rights during criminal proceeding, (Made Darma Weda.,1996).

Taking account this as background, research issue is ascertained, which is that the protection of human rights of the witness and victim during criminal proceeding is not yet given effectively. Therefore, further and deep examination of this issue is carried out through this research, Mardjono, et al., (1997).

\subsection{Problem Formulation}

The background above is underlying the following research problems:

a. How is the implementation of the right over protection of the security of the witness and victim during criminal proceeding?

b. How is the implementation of the right over giving statement without pressure of the witness and victim during criminal proceeding?

c. How is the implementation of the right over obtaining legal advice of the witness and victim during criminal proceeding?

\section{Research Method}

\subsection{Research Location}

Research is located at Jakarta and South Sulawesi. In Jakarta, the research sites include The Office of Witness and Victim Protection Organization, Supreme Court of Indonesia Republic, Supreme Attorney of Indonesia Republic, and Indonesia Advocate Association. In South Sulawesi, research sites involve High Court, High Attorney, and Local Police of South Sulawesi; High Court, High Attorney and Resort Police of Kota Besar; and Makassar Penitentiary, Bone Penitentiary, and Indonesia Advocate Association of Makassar Branch.

\subsection{Population and Sample}

The population of research includes the commissioner and employee of Witness and Victim Protection Organization, the investigator of POLRI (National Police of Indonesia), the general prosecutor, the judge, and the penitentiary officer (Barda., 1996) . The representative sample is taken through non-probability sampling technique and purposive sampling method. The sample is 150 persons, (Griffith., 1970).

\subsection{Type and Source of Data}


Type and source of data are important to support the result of research. These are:

a. Primary Data. These are obtained directly from first source (respondent) at research location.

b. Secondary Data. These are collected from certain sources, including documents and other reading literatures which are relevant to the discussion.

\subsection{Data Collection Techniques}

The author collects the data through some techniques such as:

a. Interview. It is conducted by visiting the respondent to have a direct ask-answer session with structured questions.

b. Questionnaire (a closed system). It is carried out to figure out the perception of law officer about the implementation of the protection of human rights of the witness and victim during criminal proceeding.

c. Direct Observation. It is implemented to strengthen and to support the data that are already obtained from interview and questionnaire.

\subsection{Data Analysis Techniques}

Data analysis in the inductive presentation is elaborated in the description. Qualitative analysis is applied against the qualitative data, while data collected through questionnaire are analyzed quantitatively using the tabulation of frequency. The equation is:

$\mathbf{P}=\frac{f}{N} \mathbf{x} 100 \%$

Where:

$\mathrm{P}=$ Percentage

$\mathrm{f} \quad=$ frequency at the qualification or category of variation

$\mathrm{N}$ = the frequency rate of whole classification or category of variation

\section{Result of Research And Discussion}

\subsection{The Right over Protection for Security}

The result about the opinion of respondents on the security of the witness and victim is shown in Table 1: 
Table 1. The Right over Protection for Security

\begin{tabular}{|c|c|c|c|c|c|c|c|c|}
\hline \multirow[t]{3}{*}{ No } & \multirow[t]{3}{*}{ Respondent } & \multicolumn{6}{|c|}{ Respondent Opinion } & \multirow{3}{*}{ Total } \\
\hline & & \multicolumn{2}{|c|}{ Is given } & \multicolumn{2}{|c|}{ Less Given } & \multicolumn{2}{|c|}{ Not Given } & \\
\hline & & $\mathrm{F}$ & $\%$ & $\mathrm{~F}$ & $\%$ & $\mathrm{~F}$ & $\%$ & \\
\hline 1 & $\begin{array}{l}\text { The Commissioner and } \\
\text { Employee of Witness } \\
\text { and Victim Protection } \\
\text { Organization, }\end{array}$ & 2 & 20.00 & 7 & 70.00 & 1 & 10.00 & 10 \\
\hline 2 & The Investigator & 11 & 31.42 & 21 & 60.00 & 3 & 8.57 & 35 \\
\hline 3 & The General Prosecutor & 6 & 17.14 & 27 & 77.14 & 2 & 5.71 & 35 \\
\hline 4 & The Judge & 1 & 10.00 & 7 & 70.00 & 2 & 20.00 & 10 \\
\hline 5 & The Advocate & 4 & 13.33 & 26 & 86.66 & -- & -- & 30 \\
\hline 6 & The Penitentiary Officer & 9 & 30.00 & 15 & 50.00 & 6 & 20.00 & 30 \\
\hline & Total & 33 & 22.00 & 103 & 68.66 & 14 & 9.33 & 150 \\
\hline
\end{tabular}

Table 1 above shows three options of answer, which are is-given, less-given, and not-given. The less-given for the right over protection for security is the most selected answer Mardjono, et al., (1995b). . . There are $86.66 \%$ advocate respondents admitting the less-given for the right over protection for security of the witness and victim. There are $77.14 \%$ general prosecutor respondents who ascertain about the less-given for the right over protection for security of the witness and victim, (Syafruddin., 2008). It is about $70.00 \%$ judge respondents stating that the right over protection for security of the witness and victim is less given. It is about $60.00 \%$ investigator respondents asserting that the right over protection for security of the witness and victim is also less given, (Fitriasih, at al., 2009). Finally, $50.00 \%$ penitentiary officer respondents determine that the right over protection for security of the witness and victim is less given, Mardjono, et al., (1994a). Therefore, most of respondents, or precisely 68.66 respondents, are ensured that the security of the witness and victim is less given or less protected.

\subsection{The Right over Giving Statement without Pressure}

The opinion of respondents on the right of the witness and victim over giving statement without pressure is indicated in Table 2. 
Table 2. The Right over Giving Statement without Pressure

\begin{tabular}{|c|c|c|c|c|c|c|c|c|}
\hline \multirow{3}{*}{ No } & \multirow{3}{*}{ Respondent } & \multicolumn{6}{|c|}{ Respondent Opinion } & \multirow{3}{*}{ Total } \\
\hline & & \multicolumn{2}{|c|}{ Is given } & \multicolumn{2}{|c|}{ Less Given } & \multicolumn{2}{|c|}{ Not Given } & \\
\hline & & $\mathrm{F}$ & $\%$ & $\mathrm{~F}$ & $\%$ & $\mathrm{~F}$ & $\%$ & \\
\hline 1 & $\begin{array}{l}\text { The Commissioner and } \\
\text { Employee of Witness } \\
\text { and Victim Protection } \\
\text { Organization, }\end{array}$ & 3 & 30.00 & 6 & 60.00 & 1 & 10.00 & 10 \\
\hline 2 & The Investigator & 11 & 31.42 & 20 & 57.14 & 4 & 11.42 & 35 \\
\hline 3 & The General Prosecutor & 8 & 22.85 & 19 & 54.28 & 8 & 22.85 & 35 \\
\hline 4 & The Judge & 4 & 40.00 & 5 & 50.00 & 1 & 10.00 & 10 \\
\hline 5 & The Advocate & 13 & 43.33 & 15 & 50 & 2 & 6.66 & 30 \\
\hline \multirow[t]{2}{*}{6} & The Penitentiary Officer & 17 & 56.66 & 10 & 33.33 & 3 & 10.00 & 30 \\
\hline & Total & 56 & 37.33 & 75 & 50 & 19 & 12.66 & 150 \\
\hline
\end{tabular}

Source: Processed from Primary Data (2011)

Table 2 provides three options of answer (which are is-given, less-given, and not-given). Of whole respondents (Commissioner and Employee of LPSK, Investigator, General Prosecutor, Judge, Advocate, Penitentiary Officer), there is a respondent group (Penitentiary Officer) answering that the right of the witness and victim to give statement without pressure is given, as shown by $56.66 \%$. The Commissioner and Employee of LPSK, Investigator, General Prosecutor, Judge, and Advocate have similar answer, which is that the right of the witness and victim to give statement without pressure is less given. The percentage of this answer among these respondents is varied with $60.00 \%$ for Commissioner and Employee of LPSK, $57.14 \%$ for Investigator, 54.28 \% for General Prosecutor, and 50.0 \% for Judge and Advocate, (Hulsman., 1998). The average percentage of whole respondents for their opinion about the right of the witness and victim to give statement without pressure is $37.33 \%$ for is-given, $50.00 \%$ for less-given, and $12.66 \%$ for not-given, Mardjono, et al., (1994b).

Table 3 has given three options of answer (which are is-given, less-given, and not-given). Whole six respondents (Commissioner and Employee of Witness and Victim Protection Organization,, Investigator, General Prosecutor, Judge, Advocate, Penitentiary Officer) answer that the right of the witness and victim to obtain legal advice is not given by average percentage of $69.33 \%$.

\subsection{The Right over Obtaining Legal Advice}

The right over obtaining legal advice is shown in the Table $\mathbf{3}$ as follows:

Table 3. The Right over Obtaining Legal Advice 


\begin{tabular}{|c|c|c|c|c|c|c|c|c|}
\hline \multirow{3}{*}{ No } & \multirow{3}{*}{ Respondent } & \multicolumn{6}{|c|}{ Respondent Opinion } & \multirow{3}{*}{ Tota } \\
\hline & & \multicolumn{2}{|c|}{ Is given } & \multicolumn{2}{|c|}{ Less Given } & \multicolumn{2}{|c|}{ Not Given } & \\
\hline & & $\mathrm{F}$ & $\%$ & $\mathrm{~F}$ & $\%$ & $\mathrm{~F}$ & $\%$ & \\
\hline 1 & $\begin{array}{l}\text { The Commissioner and } \\
\text { Employee of Witness } \\
\text { and Victim Protection } \\
\text { Organization, }\end{array}$ & -- & -- & 2 & 20.00 & 8 & 80.00 & 10 \\
\hline 2 & The Investigator & -- & -- & 7 & 20.00 & 28 & 80.00 & 35 \\
\hline 3 & The General Prosecutor & 1 & 2.85 & 13 & 37.14 & 21 & 60.00 & 35 \\
\hline 4 & The Judge & -- & -- & 3 & 30.00 & 7 & 70.00 & 10 \\
\hline 5 & The Advocate & 2 & 6.66 & 7 & 23.33 & 21 & 70 & 30 \\
\hline 6 & Penitentiary & 1 & 3.33 & 10 & 33.33 & 19 & 63.33 & 30 \\
\hline & Total & 4 & 2.66 & 42 & 28.00 & 104 & 69.33 & 150 \\
\hline
\end{tabular}

Source: Processed from Primary Data (2011)

The percentage of each respondent group is ordered as follows: $80 \%$ for Commissioner and Employee of Witness and Victim Protection Organization, and also Investigator, $60 \%$ for General Prosecutor, $70 \%$ for Judge and Advocate, and $69.33 \%$ for Penitentiary Officer, (Harkrisnowo, et al., 2003). Three respondents, which are Commissioner and Employee of Witness and Victim Protection Organization, Investigator and Judge, are not giving their opinion whether the right of the witness and victim over obtaining legal advice is given, Akrial, (2008)..

The advocate can be a cooperative partner during witness interrogation to produce fast, effective and efficient law enforcement. The presence of advocate during witness interrogation may influence the witness statement but it shall not be a base to justify the exclusion of advocate from being present in the witness interrogation, Mardjono, et al., (1995a).

\section{Conclusion}

\subsection{Conclusions}

After research problem, result of research, and discussion are taken account, it is concluded that:

a. The implementation of the right over protection for security of the witness and victim is not yet effective. It is confirmed by $68.66 \%$ respondents answering that the right over protection for security of the witness and victim is less-given, and $9.33 \%$ respondents are reporting not-given.

b. The implementation of the right over giving statement without pressure is not yet perfect. It is shown by $50 \%$ respondents answering that the right over giving statement 
without pressure of the witness and victim is less-given, and $12.66 \%$ respondents are reporting not-given.

c. The implementation of the right over obtaining legal advice is not effective. It is indicated by $69.33 \%$ respondents answering that the right over obtaining legal advice of the witness and victim is not-given, and $28.66 \%$ respondents are reporting less-given.

\subsection{Suggestions}

Based on these conclusions, some suggestions and recommendations are provided as follows:

a. The Act of Protection of The Witness and Victim, especially its articles regulating the organizational structure, task and authority of the Witness and Victim Protection Organization, shall be revised.

b. The effectiveness of the protection of human rights of the witness and victim during criminal proceeding must be improved by increasing coordination, professionalism, and integrity among the enforcement officers.

c. The representative of the Witness and Victim Protection Organization shall be presented in every region.

\section{Acknowledgement}

The author thanks to God and to anyone for the assistance in the research accomplishment. Special appreciation may be given to Mr. Prof. Dr. Aswanto, S.H., M.Si., DFM., as the Dean of Faculty of Law of University of Hasanuddin and Mr. Prof. Dr. Abd. Rahman SH.,MH as the Rector of University of 45 Makassar for their guidance in the implementation of this research. Mr. Andi Hamrul Sose as the General Chairman of Andi Sose Foundation and Mr. Dr. Baso Madiong SH.,MH as the Dean of Faculty of Law of University of 45 Makassar, are deserved for the author's great thanks for their funding sponsor. Mr. Abdul Haris Semendawi as the Head of Witness and Victim Protection Organization, is given grateful respect for the data or information provided for research.

\section{References}

Akrial, Zul. (2008). Policy Legal Protection Against Witness and Victim. Pekanbaru: Faculty of Law, Riau.Universitas .

Barda Nawawi Arief., (1996). Criminal Law Policy. New York: PT Citra Aditya Bakti. First published.

Fitriasih, Surastini,(2009) Witness and Victim Protection Process as a Means Toward Justice (Criminal) Honest and Fair. Jakarta: Faculty of Law, Indonesia.University.

Griffith, John., (1970). The Third Model of Criminal Process.

Harkrisnowo, Harkristuti., (2003) Witness and Victim Protection Access to Justice. Jakarta Iswanto, Yazid Effendi dan Angkasa., (1998) Viktimologi. Purwokerto: Jendral Sudirman University Publisher, First Printing.

L.H.C. Hulsman., (1998). Afscheid Van Het Strafrecht een Pleidooi Voor Zelfregulering, or 
Goodbye Criminal Law Towards Self. Regulation, Translation Wonosutanto, Surakarta: Criminal Legal Studies Forum, 1988. First published. Two Volume.

Made Darma Weda., (1996). Criminology. London: Raja Grafindo Persada, First Printing.

Mardjono Reksodiputro., (1994a). Criminology and Criminal Justice System. Jakarta: Justice and Community Legal Services (d / h Institute of Criminology), Indonesia University First Printing (First Edition).

Packer, Herbert.L. (1968). The Limit of the Criminal Sanction. Califonia:Stanford University Press:.

Syafruddin., (2008) Suspect rights to legal aid in criminal justice systems, USU School of Law, Medan.

Act 13 of (2006) on the Protection of Witnesses and Victims 